\title{
As funções do juiz no processo civil: interpretação, valoração das provas e dever de fundamentação
}

\section{The functions of the judge in civil proceedings: interpretation, valuation of evidence and duty to substantiate}

\author{
Albino Gabriel Turbay Junior ${ }^{1 *}$, Ana Claudia do Nascimento de Souza ${ }^{2}$, Laís Silva Zimiani ${ }^{3}$
}

\begin{abstract}
RESUMO
O presente artigo tem por objetivo analisar o processo civil como instrumento para o conhecimento da realidade, com enfoque na atuação do juiz no momento da interpretação da norma, da valoração das provas e no dever de fundamentação da decisão. O processo é um meio capaz de extinguir os conflitos e cabe ao Estado atuar de modo a promover a pacificação social, o que confere extrema relevância à análise das funções e deveres do juiz na condução do processo. Torna-se indispensável a demonstração da importância da adequada valoração das provas pelo magistrado e de quais meios se utilizará para a interpretação da norma, considerando seu dever legal de fundamentação das decisões, a fim de proporcionar uma decisão justa aos jurisdicionados.
\end{abstract}

Palavras-chave: Valoração das provas; Hermenêutica jurídica; Motivação das decisões.

\begin{abstract}
The present article aims to analyze the civil procedure as an instrument for the knowledge of reality, focusing on the role of the judge when interpreting the rule, evaluating the evidence and in the duty to substantiate the decision. The process is a means capable of extinguishing conflicts and it is up to the State to act in order to promote social pacification, which gives extreme relevance to the analysis of the functions and duties of the judge in conducting the process. It is essential to demonstrate the importance of proper valuation of evidence by the magistrate and what means will be used to interpret the rule, considering its legal duty to substantiate decisions, in order to provide a fair decision to the courts.
\end{abstract}

Keywords: Valuation of evidence; Legal hermeneutics; Motivation of decisions.

\footnotetext{
${ }^{1}$ Universidade Paranaense (UNIPAR). *E-mail: albinoturbay@ prof.unipar.br

${ }^{2}$ Universidade Paranaense (UNIPAR).

${ }^{3}$ Universidade Paranaense (UNIPAR).
} 


\section{INTRODUÇÃO}

A jurisdição e as funções do juiz na condução do processo devem ser devidamente compreendidas, especialmente, em relação à aproximação da verdade para a concessão da tutela jurisdicional efetiva.

O processo deve ser instrumento eficaz para desvelar a realidade e atuar como meio eficiente para solução de conflitos resistidos, para que a solução encontrada ao final do litígio seja justa e a mais próxima da verdade.

A pesquisa tem foco na forma com que o juiz realiza a interpretação da norma e como deve atuar na busca dos dispositivos que mais se adequam ao caso concreto, com o apontamento dos meios utilizados para melhor interpretação das leis.

Neste sentido é preciso analisar o papel do magistrado na valoração das provas produzidas no processo, tornando necessário o conhecimento de alguns sistemas de valoração, principalmente, o previsto pelo Código de Processo Civil de 2015.

A decisão judicial deve ser proferida com base no conjunto probatório dos autos, considerando todas as alegações postuladas pelas partes no processo, durante todo o curso processual, sendo dever legal do juiz motivar e fundamentar a sentença de forma suficiente e completa.

Nos elementos investigados incluem a interpretação, a valoração de provas e a fundamentação e motivação da sentença, que são indispensáveis para a garantia de um processo justo e comprometido com a verdade. Nessa esteira, é importante que se entenda a função jurisdicional e o processo, haja vista que são por eles que começam a se delinear a futura solução da lide resistida.

\section{PROCESSO E JURISDIÇÃO}

A vida em sociedade inevitavelmente gera conflitos, mesmo existindo normas abstratas preestabelecidas no ordenamento jurídico. Frequentemente existem interesses e excludentes simultâneos sobre um mesmo bem. Assim, os litígios resultantes rompem a paz social e por isso precisam ser solucionados de modo eficaz e justo, com a finalidade de reestabelecer a harmonia em sociedade (WAMBIER; TALAMINI, 2016, p. 105).

Desse modo, o Estado assume a responsabilidade de solucionar esses conflitos, tendo "o encargo e o monopólio de definir o direito concretamente aplicável diante das situações litigiosas, bem como o de realizar esse mesmo direito, se a parte recalcitrante 
recusar-se a cumprir espontaneamente o comando concreto da lei" (THEODORO JUNIOR, 2009, p. 35).

Para desempenhar a função supracitada estabeleceu-se a jurisdição. Para Araújo (2016, p. 280) ela "representa também uma garantia fundamental do cidadão, pois sem ela não existe meio adequado para o exercício dos direitos fundamentais". Sendo jurisdição a função "realizada pelo Poder Judiciário, tendo em vista aplicar a lei a uma hipótese controvertida, mediante processo regular, produzindo, afinal, coisa julgada, com o que substitui, definitivamente, a atividade e vontade das partes" (WAMBIER; WAMBIER, 2011, p. 346).

Destacam-se as características básicas da atividade jurisdicional, quais sejam: a) jurisdição e sua inércia (o Judiciário precisa ser provocado, chamado a solucionar o conflito), b) a atividade jurisdicional é pública, é de natureza substitutiva (o Estado, desde que seja ajuizada determinada demanda, fará realizar, em caráter de substituição, o mandamento legal que o sujeito não realizou); c) é indeclinável (e somente será exercida pelo juiz natural) e, d) possuiu a autoridade de produzir coisa julgada material (imutável) (WAMBIER; WAMBIER, 2016, p. 442-446).

Para o exercício da função jurisdicional o Estado criou órgãos especializados que se subordinam a um método, ou sistema de atuação, conhecido como processo ${ }^{4}$. Ademais, o "objeto do processo é o pedido formulado pela parte em face da relação material controvertida. A relação terá de ser examinada pelo órgão jurisdicional, mas nos limites do necessário, para solucionar o pedido" (THEODORO JUNIOR, 2009, p. 46-50).

Não obstante, Medina (2016, p. 33) afirma que "os princípios e valores dispostos na Constituição Federal constituem o ponto de partida do trabalho do processualista". Desta forma, durante o processo, caberá ao juiz, imperativamente, decidir sobre o litigio, dando razão a uma das partes. Não importa saber se o réu está de acordo com à instauração do processo ou em se submeter a decisão do juiz. Ambas as partes têm consciência de que não possuem outro lugar para buscar a solução estatal dos seus conflitos (MARINONI; ARENHART; MITIDIERO, 2016, p. 426).

O juiz, ao decidir, tem o dever de aplicar a norma ao caso concreto ou declarar que a norma clamada pelas partes processuais tem uma inconstitucionalidade. $\mathrm{O}$ processo deve ser "via que garante o acesso de todos ao Poder Judiciário e, além disto, é o conduto

\footnotetext{
${ }^{4}$ Para Marinoni, Arenhart e Mitidiero (2016, p. 158), o "processo é instrumento mediante o qual o Estado exerce poder, ditando a regra de solução do caso".
} 
para a participação popular no poder e na reivindicação da concretização e da proteção dos direitos fundamentais" (MARINONI; ARENHART; MITIDIERO, 2016, p. 160).

Ademais, um dos princípios basilares do processo é o da efetividade. O processo não deve ser entendido como um fim em si mesmo, apenas como um instrumento permeado de formalidades, mas como verdadeira garantia constitucional do jurisdicionado de buscar a concessão da tutela para efetivar seu direito material.

O juiz tem papel ativo na efetivação dos direitos fundamentais, sendo ele comprometido a converter as garantias e prerrogativas constitucionais em soluções materiais e eficazes (ARAÚJO, p. 43, 2016). Os mecanismos processuais devem propiciar, ao fim, uma decisão justa, tempestiva e útil aos jurisdicionados. Por conseguinte, no processo em que os procedimentos e consequências tenha se dado por previsão legal, haverá o respeito ao "devido processo legal" (WAMBIER; TALAMINI, 2016, p. 76).

\section{A GARANTIA DE UM PROCESSO JUSTO}

A Exposição de Motivos do Código de Processo Civil prevê que a legislação processual "tem o potencial de gerar um processo mais célere, mais justo", por atender as necessidades sociais, de forma menos complexa e, que além de objetivar a produção de um resultado justo, precisa ser justo em si mesmo e, portanto, na sua realização, devem ser observados os standards previstos na Constituição Federal, que constituem desdobramento da garantia do due process of law (BRASIL, 2010, p. 25).

Com o objetivo de permitir que sejam realizadas as garantias materiais asseguradas pela ordem constitucional, o processo precisa ser justo. E, em seu andamento, deve buscar-se "a garantia de que toda pessoa será ouvida pelo Estado para obter uma resposta adequada ao pedido" (ARAÚJO, 2016, p. 53).

Nessa linha, para que o devido processo legal seja observado, ganha destaque a aplicação do princípio do contraditório, especialmente, como previsto no Código de Processo Civil de 2015 (arts. $7^{\circ}, 9^{\circ}$ e 10), uma vez que é o princípio que garante a efetiva participação das partes no processo e estabelece a necessária dialética processual que proporcionará elementos que permitam a adequada valoração das provas e a formação da convicção judicial. 
O contraditório moderno constitui uma verdadeira garantia de não surpresa que impõe ao juiz o dever de provocar o debate acerca de todas as questões, inclusive as de conhecimento oficioso, impedindo que, em "solitária onipotência", aplique normas ou embase a decisão sobre fatos completamente estranhos à dialética defensiva de uma ou de ambas as partes. (FERRI, 2010, p. 781)

Pontua Trocker (2001, p. 386) que justo não é qualquer processo que se limita a ser regulado no plano formal. Justo é o processo que se desenvolve com respeito aos parâmetros fixados nas normas constitucionais e nos valores divididos pela coletividade. E tal é o processo que se desenvolve perante um juiz imparcial, no contraditório entre todos os interessados, e em um tempo razoável.

Conforme salienta Comoglio (1991, p. 687), o direito fundamental do indivíduo a um processo equo e giusto não se cristaliza, nem tampouco se exaure, em garantias isoladas ou singulares, mas se baseia sob uma necessária coordenação das diversas garantias concorrentes.

O comprometimento com o "justo", com a "correção", com a "efetividade" e a "presteza" da prestação jurisdicional, o due process of law realiza, entre outras, a função de um superprincípio, coordenando e delimitando todos os demais princípios que informam tanto o processo como o procedimento. Inspira e torna realizável a proporcionalidade e razoabilidade que deve prevalecer na vigência e harmonização de todos os princípios do direito processual da atualidade (THEODORO JÚNIOR, 2009, p. 27).

É possível constatar uma moderna instrumentalidade do processo, que procura preservar não apenas os escopos e perfis técnicos, mas também os aspectos éticos do procedimento judiciário, exigindo-se que as garantias formais do procedimento não sejam vistas como um fim em si mesmas, mas concorram para um resultado decisório coerente com os valores de igualdade substancial e de justiça procedimental (COMOGLIO, 1998, p. 899-900).

Registra-se que o papel do julgador de garantidor de direitos fundamentais, diretor técnico do processo, impõe a este o diálogo entre as partes para encontrar a melhor aplicação (normativa) da tutela mediante o debate processual e não por meio de um exercício solitário do poder. À comparticipação advinda da leitura dinâmica do contraditório (e de outras garantias processuais constitucionais) importa uma democratização do sistema de aplicação de tutela. Assim, resta possibilitada a aplicação 
de tutela com resultados úteis e de acordo com as perspectivas de um Estado Democrático de Direito (THEODORO JÚNIOR, 2010, p. 71).

Destarte, para que o processo seja justo e alcance seu fim primordial, que é desvelar a realidade e reestabelecer a paz entre as partes, é necessário que o agente jurisdicional (juiz) chegue a uma conclusão. Para isso, é necessário que o magistrado observe os direitos e garantias fundamentais do processo, com a devida análise de todas as alegações das partes, assim como com a valoração das provas produzidas no decorrer do processo, para que, por meio da interpretação da norma, possa exarar sua decisão, de forma clara e fundamentada.

\section{A INTERPRETAÇÃO DA NORMA: CORRENTES INTERPRETATIVAS E ESCOLAS HERMENÊUTICAS}

A interpretação tem o viés de compreensão, de percepção. O processo visa trazer à tona a verdade e assim efetivar direitos. Para alcançar este objetivo, o jurista utiliza diversos recursos sendo um deles a interpretação, sendo ela um meio de "selecionar possibilidades comunicativas da complexidade discursiva" (FERRAZ JUNIOR, 2008, p. 226,).

Conforme elucida Bittar (2019, p. 449) "a interpretação é resultante do encontro entre emissão do discurso, por parte do legislador, a recepção do discurso, por parte do interprete, e a realidade referente dos fatos". A interpretação possui papel essencial, haja vista que não raro há na norma ambiguidade, má redação, vaguidade e afins. Desse modo, cabe à interpretação "explicar, esclarecer, dar o verdadeiro significado do vocábulo, extrair da norma tudo o que nela se contém, revelando seu sentido apropriado para a vida real e conducente a uma decisão.” (DINIZ, 2013, p. 449).

Tércio Sampaio (2008, p. 267-271) consigna que a interpretação pode acontecer: de forma especificadora, restritiva e extensiva. Na primeira, parte-se do pressuposto de que o sentido da norma está na letra de seu enunciado, já na restritiva limita-se o seu sentido, sendo essa a forma de interpretação recomendada a todo preceito legal que restrinja os direitos e garantias fundamentais. Por fim, há a forma extensiva de interpretação, que amplia o sentido da norma para além do que nela está escrito.

Ademais, os textos normativos são, obviamente, formados por palavras que são tiradas da linguagem cotidiana e recebem atribuição técnica, que devem ser capazes de expressar o sentido do dever ser. É possível inferir que o propósito básico do juiz, ao 
interpretar a lei, é "determinar-lhe a força e o alcance, pondo o texto normativo em presença dos dados atuais do problema" (FERRAZ JUNIOR, 2008, p. 220-221).

Vale ressaltar, ainda, que devido ao fato da Constituição Federal ser hierarquicamente superior a todas as outras leis, a interpretação deve sempre ser feita respeitando-a. Significa que interpretar uma norma constitucional é o mesmo que atribuir um significado a um ou vários símbolos linguísticos escritos na constituição com o fim de se obter uma decisão de problemas práticos normativo-constitucionalmente fundada (CANOTILHO, 2003, p. 1200).

Quando se interpreta um tex to legal deve-se buscar os seus fins sociais e os valores que ele buscava garantir, exatamente como consagrado no art. $8^{\circ}$ do Código de Processo Civil, que impõe ao juiz, ao aplicar o ordenamento jurídico, o dever de atender aos "fins sociais e às exigências do bem comum, resguardando e promovendo a dignidade da pessoa humana e observando a proporcionalidade, a razoabilidade, a legalidade, a publicidade e a eficiência".

Nesse contexto, verifica-se a relevância da hermenêutica, que "contém regras bem ordenadas que fixam os critérios e princípios que deverão nortear a interpretação" (DINIZ, 2013, p. 450). Assim, a interpretação deve ser feita com o objetivo de apurar o conteúdo, o sentido e os fins das normas jurídicas e a restauração do conteúdo orgânico do direito, para o efeito de sua aplicação (RÁO, 1997, p. 452).

Historicamente, o primeiro processo hermenêutico foi o gramatical/filológico que se consubstancia no estudo específico da verba legis, atendendo aos princípios de que as palavras podem ter sentido jurídico diverso do corrente ou vulgar e que elas não devem ser examinadas isoladamente, mas, em seu conjunto. Em seguida, acrescentou-se a ele o processo lógico, com as princípios da lógica formal chegando a abstrair-se daí três processos: a) lógico-analítico, ocupando-se de descobrir a finalidade da lei; b) o lógico sistemático, que referia o texto ao contexto normativo de que faz parte - direito comparativo e; c) lógico jurídico, que investigaria os elementos criadores do preceito legal, tais como as razões que justifiquem a norma, a sua circunstância histórica e eficácia normativa (MACHADO NETO, 1984, p. 217).

Há também, o processo interpretativo sociológico que busca "adaptar a finalidade da norma às novas exigências sociais". Com isso, essa técnica pretende encontrar a finalidade da norma para então dar o seu sentido (DINIZ, 2013, p. 460-461).

Outrossim, há várias escolas hermenêuticas e em cada qual há o seu processo interpretativo. A escola tradicional divide-se em dogmática - ou escolástica - e exegese. 
A primeira com a pretensão de aliar o Direito aos textos rígidos. Buscava-se a vontade primária do criador do dispositivo a fim de conhecer o seu sentido. Na Escola Exegese investigava-se a vontade do legislador. Para tal, ia-se de artigo em artigo até construir, entre centenas de normas, um todo orgânico (MAXIMILIANO, 1999, p. 44-46). ${ }^{5}$

Não obstante, Magalhães (1989, p. 17-18) cita que as duas escolas, sendo a dogmática de origem alemã e a exegese de gênese francesa, tem em comum a idolatria aos códigos e as leis, assim, o autor acrescenta que "o apego à lei e à utilização de processos lógicos, caracterizadores da Hermenêutica Tradicional, não são a ela peculiares, mas frutos de um longo evolver histórico, social, político, jurídico e filosófico".

Para Maximiliano (1999, p. 47), a escola histórico-evolutivo, devido a impossibilidade de mudar as normas em intervalos breves, usava-se da adaptação do dispositivo para alcançar às exigências sociais que antes eram imprevistas, moldando o texto normativo a fim de que ele atenda às necessidades práticas. Pelo processo históricoevolutivo há a intenção de "fecundar a letra da lei na sua imobilidade, de maneira que se torne esta a expressão real da vida do Direito". Caberá ao juiz interpretar a lei "humanamente", buscando eleger, dentre os sentidos que ela oferece, o que mais atenda ao bem comum e a equidade (SILVEIRA, 1985, p. 147).

Sobre essa escola Paulo Nader (2015, p. 283) preceitua:

O Direito, por definição, deve ser um reflexo da realidade social. Ora, se a realidade evolui e a lei se mantém estática, o Direito perde sua força. Em vez de promover o bem social, vai criar problemas e atravancar o progresso. De certa forma o Poder Judiciário vai suprir as deficiências do Legislativo, que se revelou negligente, permitindo a defasagem entre a vida e o Direito. Não se conclua daí a intromissão de poderes. O Judiciário, assim procedendo, não cria o Direito, apenas revela novos aspectos de uma lei antiga.

Ademais, outra escola hermenêutica de grande relevância é a da Livre Pesquisa, ou da livre formação do direito. Nesta, há duas vertentes: a romântica e a científica. Sendo a primeira ligada ao bom juiz Magnaud e a propriedade científica, já a segunda, no entanto, possuía uma posição extremada e outra moderada (ANDRADE, 1992, p. 42).

\footnotetext{
${ }^{5}$ Nesse sentido, a ideia norteadora era a de que "se uma teoria não tem suas raízes nos textos, nem no espírito da lei, deve ser rejeitada; ao contrário, será jurídica se expressa na letra da lei e nos trabalhos preparatórios. Nesses casos, deve ser aceita, não recuando diante de alguma consequência" (LAURENT, 1878, p. 348 apud NADER, 2015, p. 281).
} 
A vertente romântica é constantemente ligada a figura do magistrado Magnaud pois suas sentenças eram livres de peias legais e estavam diretamente ligadas as suas propensões sentimentais (FRANÇA, 1988, p. 38).

Na orientação científica extremada tinha-se que o juiz, ao buscar o ideal jurídico, podia decidir além da lei e, também, contra a lei, usando por base a experiência, os dados sociológicos e até mesmo o foro íntimo, enquanto na orientação científico-moderada "o juiz tem liberdade ampla, relativamente criadora, em falta de disposição escrita ou costumeira" (ANDRADE, 1992, p. 42).

Faz-se necessário delinear os principais aspectos dos métodos interpretativos. $\mathrm{O}$ elemento gramatical, também chamado de literal ou filológico trata-se de método que analisa o valor semântico das palavras empregadas no texto, da sintaxe, e demais elementos da linguagem. Na modernidade ele visa evitar o abuso dos que se apegam a literalidade da lei, pois o processo meramente literal prejudicaria a mens legis - o espírito da lei (NADER, 2015, p. 276). Ainda assim, a "(...) interpretação gramatical obriga o jurista a tomar consciência da letra da lei e estar atento às equivocidades proporcionadas pelo uso das línguas naturais e suas imperfeitas regras de conexão e léxica" (FERRAZ JUNIOR, 2008, p. 253).

Já o elemento lógico, para Tércio Sampaio (2008, p. 253), é parte "(...) do pressuposto de que a conexão de uma expressão normativa com as demais do contexto é importante para a obtenção do significado correto". Na lição de Paulo Nader (2015, p. 277-278), este método pode ser dividido em interno, externo e razoável. No interno, o intérprete submete a lei à ampla análise e a lei é estudada dentro de sua unidade de pensamento, através dos métodos dedutivo, indutivo e dos raciocínios silogísticos. O externo orienta-se pela observação dos acontecimentos que provocaram a formação do fenômeno jurídico, indagando-se, ainda, os fins que ditaram as regras jurídicas. E a lógica do razoável defende o respeito a mens legis, além de dizer que a interpretação deve levar em consideração a finalidade da regra jurídica, haja vista que o direito é circunstancial, pois depende das condições, necessidades sentidas e efeitos que trata de produzir mediante uma lei.

Sobre o elemento sistemático, é possível afirmar que se considera, harmonicamente, todos os atos legislativos, além de todas as normas costumeiras vigentes: 
(...) qualquer preceito isolado deve ser interpretado em harmonia com os princípios gerais do sistema, para que se preserve a coerência do todo. Portanto, nunca devemos isolar o preceito nem em seu contexto (a lei em tela, o código: penal, civil etc.) e muito medos em sua concatenação imediata (nunca leia só um artigo, leia também os parágrafos e os demais artigo). (FERRAZ JUNIOR, 2008, p. 257)

A interpretação histórica, por saber que o direito é uma força viva que se renova e aperfeiçoa-se para atender os desafios de novos tempos, há o entendimento de que o fenômeno jurídico é resultado da história e, por isso, enfatizam a importância do estudo do histórico da lei para a sua boa interpretação (NADER, 2015, p. 279).

E por fim, a interpretação teleológica (ou axiológica), ativa a participação do intérprete na configuração do sentido. Ao contrário da interpretação, parte das consequências avaliadas das normas e retorna para o interior do sistema. Para o hermeneuta, a norma deve sempre ter um objetivo que serve para controlar até as consequências da previsão legal (a lei sempre visa os fins sociais do direito e às exigências do bem comum, ainda que, de fato, possa parecer que eles não estejam sendo atendidos) (FERRAZ JUNIOR, 2008, p. 267).

Com a análise das principais escolas hermenêuticas, e de alguns modos de interpretação, outro ponto relevante a ser analisado é o da vontade, se o que prepondera é a da lei ou a do legislador.

Existem duas correntes em relação ao tema. A que considera a vontade do legislador é a subjetivista e a que valora a vontade da lei é a objetivista. A primeira, por considerar a ciência do direito como saber dogmático, insiste que a interpretação é basicamente uma compreensão do pensamento do legislador. No entanto, para os objetivistas as normas possuem sentido próprio, independentes - até certo ponto - do sentido que o legislador queria dar. Sendo assim, a interpretação se dá ressaltando aspectos estruturais e sociológicos (STRECK, 2004, p. 101).

Nessa linha, é importante conhecer também o grau de liberdade dada ao judiciário. A proposta inaugural - dada pela doutrina - é a livre estimação, preconizou uma ampla liberdade para os juízes, que poderiam aplicar o direito consoante os princípios de equidade. Na corrente doutrinária da Limitação à Subsunção, o juiz não coopera com sua experiência, não adapta o ordenamento a realidade. Seu papel é apenas operar os critérios rígidos da norma jurídica. Entretanto, como ponto de equilíbrio, há a terceira corrente Complementação Coerente e Dependente de Preceito - que concilia o respeito ao direito vigente e a margem de liberdade aos juízes (NADER, 2015, p. 173-176). 
Com a análise das correntes interpretativas e das escolas hermenêuticas apresentadas, resta dizer que o intuito delas é fornecer ao juiz caminhos para compreender as disposições legais e assim chegar à sua convicção de forma congruente, para que extraia da norma a melhor solução para os fatos revelados no curso processual e para que conceda a tutela dos direitos buscados pelas partes. Para que se obtenha esse resultado, ao exarar a sentença, o agente jurisdicional, durante o processo, deve analisar detalhadamente todas provas e alegações que lhe forem apresentadas, a fim de proporcionar o resultado mais justo.

\section{A VALORAÇÃO DAS PROVAS}

No processo haverá duas espécies de debates: o primeiro incide sobre as teses jurídicas alegada pelas partes, versando sobre a interpretação do direito, já a segunda tem por objeto os argumentos de fato que se encontram na base do litígio, e nesse campo muito se pode discutir sobre a função da prova (MARINONI; ARENHART; MITIDIERO, 2016, p. 257).

A atividade probatória desenvolvida no processo não se satisfaz com a mera recomposição formal dos fatos, as provas produzidas devem ser suscetíveis de indicar, do modo mais aproximado possível da realidade, como os fatos ocorreram (MEDINA, 2016, p. 635).

A prova é um dos instrumentos capazes de chegar o mais próximo possível da verdade por trás das alegações das partes. O uso da expressão "o mais próximo da verdade" é utilizada, pois seria utópico pensar que é possível alcançar uma verdade absoluta. No entanto, o juiz não pode permanecer incerto a respeito dos fatos que tem que decidir; deve de qualquer forma (essa é sua função) resolver a controvérsia numa certeza jurídica (CALAMANDREI, 1999, p. 270-271).

O direito a prova está previsto em vários tratados internacionais incorporados ao direito brasileiro, além de ser também um direito fundamental. A oportunidade de requerer provas, de produzi-las, de participar de sua produção, de manifestar-se sobre elas e delas serem examinadas por um órgão julgador, após produzidas, é direito básico que deve ser respeitado durante o processo (DIDIER JR; BRAGA; OLIVEIRA, 2016, p. 4647). 
Sobre o destinatário da prova, Medina (2016, p. 628) pontua que, tradicionalmente, considerava-se o juiz como tal, contudo, modernamente entende-se que as partes também o são.

As provas "não tem por finalidade apenas propiciar o convencimento do juiz, senão também convencer as partes, permitindo-lhes decidir acerca das condutas que vão adotar no processo ou mesmo fora dele" (DIDIER JR; BRAGA; OLIVEIRA, 2016, p. $57)$.

Após produzidas, as provas integrarão o acervo instrutório - pouco importando qual das partes teve a iniciativa de requerer sua produção. Isso tudo para que o magistrado possa se valer delas e formar sua convicção (WAMBIER; TALAMINI, 2016, p. 227). Destaca-se que a importância é revelada pelo fato de que o juiz tem o poder-dever de requerê-las de ofício, independentemente de pedido da parte ou qualquer outro participante do processo, quando os fatos não lhe parecerem esclarecidos (MARINONI; ARENHART; MITIDIERO, 2016, p. 267).

Sobre o tema da valoração das provas pelo magistrado, existem três correntes: a íntima convicção, a prova legal e a prova livre. Nessa última não há critérios fixadores de valoração e o momento de valorar é fruto da criação do juiz. Caberia a ele decidir o valor de cada prova de acordo com o caso concreto. Contudo, não há que se pensar que o magistrado tem ampla discricionariedade em sua valoração. Na realidade cabe ao agente jurisdicional pautar seu convencimento em critérios lógico-racionais (BORGES, 2017, p. 155-179).

Já na íntima convicção o juiz não precisaria, no processo de formação de seu convencimento, apoiar suas decisões conforme as provas que foram produzidas no processo. Os magistrados teriam liberdade plena para buscar a verdade e avaliar os meios probatórios apresentados. Sua convicção formar-se-ia independentemente de parâmetro racional (podendo basear sua convicção em provas fora dos autos ou até mesmo contra os autos (COUTURE, 2002, p. 223).

Por esta corrente, portanto, ao juiz é permitido decidir conforme seu sentimento, de acordo com seus valores pessoais e com sua consciência. Evidentemente trata-se de um sistema que não se preocupa com a discricionariedade do julgador, conflitando de forma inquestionável com os princípios decorrentes do devido processo legal, e, por este motivo, inviável no direito moderno.

Em contrapartida, na prova legal, a lei banaliza a valoração dos fatos que irão servir de fundamento para decisão. Nesse sentido, é imposta ou impedida a eficácia 
persuasiva de uma prova em determinado contexto. A prova legal pode ter sentido positivo, quando a norma jurídica impõe ao magistrado que ele adote determinada conclusão em virtude de certa e determinada prova e; sentido negativo, quando a lei proíbe que o juiz defenda uma dada conclusão de um dado meio de prova (BORGES, 2017, p. 155-179). Neste sistema, que era adotado pelo direito romano primitivo e pelo medieval, o processo produzia apenas uma verdade formal, que na grande maioria dos casos não tinha vínculo com a realidade (THEODORO JUNIOR, 2007, p. 475).

Contudo, apesar da importância desses meios de valoração, a regra geral de modo de recepção de provas do Código de Processo Civil de 2015 diverge dessas correntes. A prova deve ser valorada pelo juiz de acordo com o artigo 371 do CPC, que dispõe que ele deve apreciar a prova constante dos autos, independentemente do sujeito que a tiver promovido, e deve indicar na decisão as razões da formação de seu convencimento.

Diferente do que previa o Código de Processo Civil de 1973, em seu artigo 131, o Código de Processo Civil de 2015 retira expressão "livremente", ao determinar a forma com que o juiz recepcionará as provas, demonstrando que não admite qualquer carga de irracionalidade em relação as provas (MEDINA, 2016, p. 667). Na mesma linha, Didier, Braga e Oliveira (2016, p. 106) destacam que:

(...) o convencimento do juiz tem de ser motivado - o convencimento não é livre, nem pode ser íntimo, como acontece no Tribunal do Júri. O órgão julgador deve apresentar as razões pelas quais entendeu que a prova merece o valor que lhe foi atribuído. Por isso, dá-se a esse sistema o nome de "convencimento motivado" ou "persuasão racional".

Nesse sentido, por respeito ao princípio do contraditório, não se aceita a valoração de prova que não foi produzida e não consta nos autos, uma vez que se lá não estava, pelo menos uma das partes, não teve acesso a ela. Ademais, não pode o magistrado valorar provas irracionalmente, pois espera-se que a motivação seja comumente reconhecida e aceita no contexto da cultura daquele tempo. Não pode o julgador valorar provas que vão contra as regras de experiências máximas, como por exemplo não aceitar as regras da gravidade (DIDIER; BRAGA; OLIVEIRA, 2016, p. 107-110). O sistema de valoração de provas é de extrema relevância, porque preserva a independência da função jurisdicional e afasta o perigo de arbítrios, caprichos e subjetivismos excessivos (WAMBIER; TALAMINI, 2016, p. 231). 
Não obstante, embora possa o juiz valorar as provas e formar seu convencimento, deve respeitar os limites normativos. O juiz deve indicar na sua decisão o porquê de determinada prova não o convencer (não apenas valorar as provas da parte que o fez chegar a uma determinada conclusão). Nesse seguimento, explicam Marinoni, Arenhart e Mitidero (2005, p. 461) que o magistrado não pode deixar de demonstrar que as eventuais provas produzidas pela parte perdedora não lhe convenceram, é preciso eliminar a ideia de que justificar decisão é o mesmo do que lembrar as provas e argumentos que servem ao vencedor.

E é por essa razão que sempre será necessário que o juiz justifique o porquê de não ter dado valor aos outros meios de prova, que sustentariam a conclusão diversa (MARINONI; ARENHART; MITIDIERO, 2016, p. 271).

Assim, após o juiz compreender os fatos e chegar a uma conclusão, tem ele o dever de, na sua decisão, deixar claro a razões pelas quais determinada prova o convenceu e o motivo de outra não ter logrado tal feito. Assim, Medina (2016, p. 672) afirma que um fato "está provado" quando o juiz consegue atestar, objetiva e racionalmente, a coerência entre o que se alegou e os elementos obtidos com a atividade probatória.

Desse modo, nota-se que o Estado, após provocado e figurado na pessoa do juiz, buscará durante o processo - por meio da análise das provas - a solução mais justa e heterônoma. Para isso, obviamente, tem poderes para identificar a solução mais adequada e assim aplicar a norma que mais se adequa ao caso concreto. Não obstante, é impreterível que haja a valoração das provas na sentença, sendo que:

A decisão que valorar a prova deverá ser dotada de completude, coerência, congruência e correção lógica: completude (se todas as provas disponíveis forem levadas em consideração), coerência (se a valoração do conjunto das provas não contiver contradições internas, apresentando conclusões convergentes), congruência (se as provas levadas em consideração efetivamente disserem respeito aos fatos em apuração) e correção lógica (se as interferências do raciocínio forem logicamente válidas e justificáveis). (MEDINA, 2016, p. 672)

A exigência da valoração das provas se justifica como forma de evitar "juízos discricionários", "puramente subjetivos" "solipsistas" do julgador; além disso, a exigência serve para permitir e facilitar o controle da decisão" (DIDIER; BRAGA; OLIVEIRA, 2016, p. 106). 
Didier, Braga e Oliveira (2016, p. 54) salientam que a justiça de uma decisão não se baseia apenas em seguir todas as garantias processuais durante o processo e, depois, interpretar e aplicar a norma correta. Tudo isso, por óbvio, é demasiadamente importante, no entanto, uma decisão só será realmente justa se for baseada em uma reconstrução verdadeira dos fatos discutidos no processo.

Para que a decisão seja justa, é necessário que se garanta um processo justo, com a incidência do contraditório dinâmico, por meio da dialeticidade processual e da participação efetiva das partes, observando-se a cooperação de todos os sujeitos processuais, para que a tutela jurisdicional seja adequadamente concedida.

Portanto, pode se dizer que o direito de participação por intermédio da produção de provas constitui elemento indissociável do direito ao processo justo, que constitui toda a estrutura do direito processual civil brasileiro (MARINONI; ARENHART; MITIDIERO, 2016, p. 259).

Assim, diante da importância do momento processual que abarca a produção ampla de provas, como meio de amparar as alegações das partes e para reconstruir os fatos, vê-se que o papel do juiz de valorar as provas é crucial para a construção de uma decisão justa a partir da compreensão da realidade dos fatos, sendo essencial a compreensão do dever de fundamentação das decisões judiciais.

\section{O DEVER DE FUNDAMENTAÇÃO DA DECISÃO JUDICIAL}

O objetivo do processo, e de seu desenvolvimento de forma justa, é entregar a prestação jurisdicional com a resolução do conflito apresentado, assim, após as partes mostrarem suas alegações e seus argumentos, bem como a concessão de oportunidade para impugnações, organização do processo e produção de prova, deverá o juiz decidir a lide, não podendo se eximir de decidir sob a alegação de lacuna ou obscuridade do ordenamento jurídico (art. 140, CPC/15).

Mas a sentença proferida após o desenvolvimento do processo com o intuito de solucionar o conflito aplicando o direito ao caso concreto, não é o único momento em que o juiz decidi no processo, pois, durante as fases do procedimento o juiz toma outras decisões (chamadas de decisões interlocutórias), como, por exemplo, para decidir sobre tutelas de urgência ou decidir na fase de saneamento do processo.

Neste sentido, cabe ao magistrado também "(...) não só em sentença, mas como em qualquer decisão judicial, o dever de fundamentar especificadamente todas as 
questões suscitadas pelas partes, sendo sucinto ou não" (PAULA, 2016, p. 418). E, entende-se por "fundamentar", a apresentação racional das bases fáticas e jurídicas da decisão (MEDINA, 2016, p. 747). Nesse sentido, Wambier e Talamini (2016, p. 434) afirmam:

$\mathrm{Na}$ fundamentação, cabe ao magistrado expor as razões de seu convencimento, de forma clara, completa e razoável, de modo a que todos aqueles que a leiam possam compreender o caminho argumentativo que o levou à conclusão a que chegou. Trata-se de norma em que se concretiza de forma inequívoca o princípio do livre convencimento motivado, tal como expresso no art. 371.

A motivação (inserido o dever de fundamentação) é a espinha dorsal que sustenta o corpo da sentença. O dever de fundamentar tem raiz na Constituição Federal, conforme explicitamente previsto em seu artigo 93, inciso IX, sendo que o Estado de Direito não permite que a motivação das decisões judiciais nasça sponte propria, ou seja, de forma arbitrária, mas, sim, com base na norma jurídica e com o subsídio das provas carreadas ao processo, em amplo contraditório (ARAÚJO, 2016, p. 154).

A necessidade de fundamentar decorre, também, da ideia de recorribilidade. Uma decisão, em princípio, para ser efetivamente controlável quanto ao acerto de suas conclusões, precisa ser analisável e criticável na sua base: a fundamentação (WAMBIER; TALAMINI, 2016, p. 435).

Por conta disso, uma decisão não fundamentada é nula. Seu defeito é tão grave quanto a ausência de citação do réu, haja vista que a parte tem o direito de saber o motivo da decisão judicial. Se assim não fosse, instaurar-se-iam o totalitarismo e a arbitrariedade no processo (ARAÚJO, 2016, p. 154).

A fundamentação é ato de inteligência, porque demonstra como o juiz chegou até a norma que solucionará a lide, além de demostrar a forma com que ele compreendeu os fatos; é ato de declaração, quando o magistrado interpreta e aplica a norma, revelando com exatidão o sentido da regra jurídica e, por fim, é ato de resposta, pois ao fim do processo o juiz dará uma resposta conclusiva ao que foi litigado (MEDINA, 2016, p. 749).

A sentença, de acordo com o art. $203, \S 1^{\circ}$, do CPC/2015, é definida pelo momento processual em que é proferida (já que "põe fim" ao processo ou "fase" processual) e, também, pelo conteúdo, cumulativamente" (MEDINA, 2016, p. 733) e pode ser vista "como um ato processual que assinala o momento em que o perfil da técnica processual 
se altera: adotando-se as técnicas pré-ordenadas à execução dos direitos" (MARINONI; ARENHART; MITIDIERO, 2016, p. 317)

No relatório, o juiz tem de fixar de forma cronológica todos os fatos jurídicos relevantes que ocorreram no processo. Mais que isso, é necessário também que no relatório conste o resumo do que foi postulado pelas partes, devendo ficar demonstrando que o juiz entendeu o que lhe foi pedido. Se assim for, ao ler-se o relatório ficará claro quais fatos, dentre os que ocorreram no iter processual, foram considerados relevantes e levados em consideração. Dessa forma, o relatório é também manifestação do dever de fundamentar a decisão judicial (MEDINA, 2016, p. 750). Inclusive, a falta ou absoluta deficiência do relatório podem afetar, nesse sentido, a própria motivação da sentença (WAMBIER; TALAMINI, 2016, p. 433).

Outro elemento essencial da sentença é o dispositivo, que nada mais é do que o resumo da fundamentação e deve, obrigatoriamente, guardar coerência e equivalência entre si. E é importante frisar que não importa saber quais foram as razões psíquicas que levaram o juiz a tomar uma decisão. O que é relevante para a fundamentação é responder se há ou não razões jurídicas capazes de suportar, de forma valida, a tomada da decisão (MARINONI; ARENHART; MITIDIERO, 2016, p. 319).

A fundamentação é o momento em que o magistrado demonstra as questões fáticojurídicas trazidas ao processo pelas partes, o que inclui obviamente a valoração das provas e as razões jurídicas que o levaram a decidir as questões processuais e as questões materiais da causa da maneira como decidiu. A atividade interpretativa do magistrado tem de ser racional. E, para ser racional, deve ser justificada. Nesse sentido, se justificada e assim racional, o resultado da interpretação será coerente e universalizável (MARINONI; ARENHART; MITIDIERO, 2016, p. 320).

A exigência de pronunciamento racional e fundamentado não impõe a obrigação de uma decisão extensa, pois "a fundamentação suscinta não acarreta omissão quando o pedido da demanda é apreciado na integra" (MEDINA, 2016, p. 759).

O artigo 489 do Código de Processo Civil é categórico em relação ao dever de fundamentação do magistrado, demonstrando em seu $\S 1^{\circ}$ que a decisão judicial não será fundamentada se houver quaisquer das condutas indicadas em seus incisos, como: I) a limitação à indicação, à reprodução ou à paráfrase de ato normativo, sem explicar sua relação com a causa ou a questão decidida e; II) o emprego de conceitos jurídicos indeterminados, sem explicar o motivo concreto de sua incidência no caso. 
A redação do inciso III do referido artigo indica que a decisão judicial não é fundamentada quando invoca motivos que se prestariam a justificar qualquer outra decisão. Tal redação deixa claro que ao legislador não interessa decisões não individualizadas, assim sendo, repele a possibilidade do juiz usar decisões-modelos indistintamente, sem motivar realmente o caso concreto (WAMBIER; TALAMINI, 2016, p. 434).

Ainda, no mesmo artigo, o inciso IV prevê que não será fundamentada a decisão que não enfrentar todos os argumentos deduzidos no processo capazes de infirmar a conclusão adotada pelo julgador. Tal disposição é uma das mais polêmicas, vez que obriga o magistrado a esclarecer todos os argumentos que são capazes de contrariar a conclusão adotada por ele. Contudo, trata-se de dever legal, pois caso contrário, a garantia do direito de defesa e de produção de provas cairia por terra, uma vez que não ficaria claro quais argumentos foram aceitos e quais foram rejeitados (ARAÚJO, 2016, p. 159).

Já o inciso $\mathrm{V}$, do $\S 1^{\circ}$, art. 489 do CPC deixa claro que a decisão não será fundamentada, caso o juiz se limite a invocar precedente ou enunciado de súmula, sem identificar os fundamentos determinantes nem demonstrar que o caso sob julgamento se ajusta àqueles fundamentos. Isso ocorre, pois a fundamentação deve ser analítica, com a identificação precisa dos fundamentos determinantes da formação da tese jurídica e com a demonstração do porquê são apropriados ao caso concreto (WAMBIER; TALAMINI, 2016, p. 435).

Por fim, conforme estabelecido no inciso VI, não deve o juiz se deixar guiar por orientação firmada na jurisprudência, sem demonstrar que o caso a ser julgado é diferente (distinguishing) ou que a orientação referida encontra-se superada (overrulling) (MEDINA, 2016, p. 756).

Sobre a colisão de normas, o parágrafo $2^{\circ}$, do art. 489 do CPC estabelece que o juiz deve justificar o objeto e os critérios gerais da ponderação efetuada, enunciando as razões que autorizam a interferência na norma afastada e as premissas fáticas que fundamentam sua conclusão (PAULA, 2016, p. 419).

O parágrafo $3^{\circ}$ do mesmo dispositivo, prevê que a decisão judicial deve ser interpretada a partir da conjugação de todos os seus elementos e em conformidade com o princípio da boa-fé, para que seja considerada fundamentada (BRASIL, 2015).

Em síntese, para que uma decisão possa ser considerada como fundamentada, exige-se: 
(i) a enunciação das escolhas desenvolvidas pelo órgão judicial para, (i.i) individualização das normas aplicáveis; (i.ii) verificação das alegações de fato; (i.iii) qualificação jurídica do suporte fático; (i.iv) consequência jurídicas decorrentes da qualificação jurídica do fato; (ii) o contexto dos nexos de implicação e coerência entre tais enunciados e (iii) a justificação dos enunciados com base em critérios que evidenciam a escolha do juiz ter sido racionalmente apropriada". (MARINONI; ARENHART; MITIDIERO, 2016, p. 322)

Admitir a validade de uma decisão sem fundamentação é o mesmo que agredir o devido processo legal e mostrar a face da arbitrariedade, o que é incompatível com um judiciário democrático (MEDINA, 2016, p. 751).

A fundamentação da sentença constitui uma exigência do princípio da tutela judicial efetiva, cuja última razão reside na proibição da arbitrariedade e que, portanto, na necessidade de evidenciar de que o julgamento não é um simples e arbitrário ato de vontade do julgador, mas senão uma decisão razoada nos termos do Direito (PAULA, 2016, p. 416).

Dessa forma, a sentença deve ser racional, justificada interna (o magistrado, para interpretar, deve seguir uma linha lógica, justificando completamente a decisão e não deixando existir na sentença contradições) e externamente (seguindo uma linha argumentativa, oferecendo razões que sustentem as individualizações, valorações e escolhas realizadas para a composição de sua convicção). A sentença deve ser capaz de ser reconduzida e concatenada a um conjunto de princípios e regras comuns, além de precisar ser universal, e com isso ser capacitada a replicação em casos futuros - que sejam semelhantes ou idênticos (MARINONI; ARENHART; MITIDIERO, 2016, p. 320).

A fundamentação das decisões, é necessária para que a decisão judicial possa ser qualificada como justa e sobre sua leitura se realize o controle sobre o seu acerto (ARAÚJO, 2016, p. 156).

Destarte, quando o juiz fundamenta suas decisões, reduzem-se as chances de ocorrência de arbitrariedades ou discricionariedades. No curso processual e após analisar todas as alegações das partes, valorar as provas produzidas nos autos e interpretar a norma aplicável ao caso (com a observância do devido processo legal), a fundamentação específica da sentença gera o resultado útil do processo e confere justiça à decisão judicial, contribuindo com a natureza democrática e participativa do processo e atuando diretamente na efetivação dos direitos dos jurisdicionados.

\section{CONCLUSÃO}


A jurisdição é entendida como poder do Estado quando atua na aplicação da norma jurídica, em casos em que um impasse de interesses seja qualificado por uma pretensão resistida. A atividade jurisdicional tem a função de definir o direito aplicável na situação litigiosa e de realizar esse mesmo direito, caso a parte se negue a cumprir o comando da lei. A função jurisdicional depende de provocação, tem natureza pública e substitutiva, é indeclinável e possui autoridade para formar a coisa julgada material.

O processo judicial se inicia com o pedido formulado pelo jurisdicionado em face da relação material controvertida. O processo é verdadeiro garantidor de acesso ao Poder Judiciário, é o meio que viabilizar a reivindicação da concretização e da proteção dos direitos fundamentais. Caberá ao juiz analisar as alegações das partes, com a verificação da relação material e processual, organizar o processo, estabelecer o contraditório, proceder à instrução e decidir sobre o litígio, concedendo a tutela ou negando-a de acordo com o que foi apurado processualmente.

A função do juiz é imprescindível para a efetivação dos direitos fundamentais, uma vez que tem o compromisso de converter garantias e prerrogativas constitucionais em soluções eficazes. No andamento processual, deve o juiz garantir que toda pessoa será ouvida para obter uma resposta adequada ao pedido, em respeito ao devido processo legal e a todos os princípios constitucionais e processuais que fazem nascer o processo justo, com destaque ao princípio do contraditório dinâmico, que deve observar a efetiva participação das partes no processo.

Assim, o processo é instaurado para que a realidade seja conhecida e possibilite a concreta efetivação de direitos. É primordial, portanto, o conhecimento das correntes interpretativas e das escolas hermenêuticas, vez que fornecem ao juiz caminhos para compreensão das disposições legais e para formação de sua convicção. A interpretação deve ser uma ferramenta utilizada com cautela pelo julgador, pois será resultante do encontro entre emissão do discurso, por parte do legislador, a recepção do discurso, por parte do intérprete, e a os fatos. É a interpretação da norma que explica, esclarece e dá sentido à norma para ser aplicada à vida real e conduza a uma decisão.

E para que a norma seja interpretada, é essencial que os fatos sejam conhecidos por meio da alegação das partes e pela valoração das provas produzidas no processo. $\mathrm{O}$ sistema de valoração das provas já foi entendido de formas diversas, como: da íntima convicção, da prova legal e da prova livre. O Código de Processo Civil de 2015 adotou a corrente da "persuasão racional", que determina que o juiz, ao apreciar a prova, 
independentemente do sujeito que a tiver promovido, deverá pontuar na decisão as razões da formação de seu convencimento, que não pode ser dotado de subjetivismos e por critérios alheios à norma jurídica.

Nessa linha, o dever de fundamentação das decisões aparece com especial destaque no Código de Processo Civil de 2015 em seu artigo 489. A fundamentação é ato de inteligência, de declaração e de resposta, é o momento em que o juiz analisa as questões fático-jurídicas, incluindo, a valoração das provas e as razões jurídicas que o levaram a decidir as questões processuais e as questões materiais da causa. Uma decisão sem fundamentação no processo é inadmissível e viola frontalmente o devido processo legal, demonstra a inaceitável arbitrariedade e é absolutamente incompatível com o sistema judiciário democrático brasileiro.

Verifica-se, assim, que a norma jurídica impõe ao juiz a compreensão da realidade dos fatos apresentados para julgamento. Quando o juiz interpreta, valora as provas produzidas no processo e fundamenta especificadamente suas decisões, está exercendo a jurisdição de forma plena a fim de construir um processo justo, respeitando sua natureza democrática e participativa e, gerando um resultado útil por meio da efetivação dos direitos das partes.

\section{REFERÊNCIAS}

ANDRADE, C. J. O Problema dos métodos da interpretação jurídica. São Paulo: Revista dos Tribunais, 1992.

ARAÚJO, F. C. Curso de processo civil. São Paulo: Malheiros, 2016.

BITTAR, E. C. B. Introdução ao estudo do direito: humanismo, democracia e justiça. 2. ed. São Paulo: Saraiva, 2019.

BORGES, R. S. O sistema misto de valoração da prova no novo código de processo civil: a relação entre prova livre e prova legal. Revista de Processo. n. 264. São Paulo. p. 155 - 179. Fev. 2017.

BRASIL. Código de processo civil: Lei n. 13.105, de março de 2015. Brasília: Senado Federal, Secretaria de Editoração e Publicações, 2015.

BRASIL. Constituição da República Federativa do Brasil de 1988. Brasília, DF: Presidência da República. Disponível em: https://www.planalto.gov.br/ccivil_03/constituicao/constituicao.htm. Acesso em: 17 set. 2020. 
BRASIL. Exposição de motivos do código de processo civil. Brasília, 8 de junho de 2010. Disponível em:

<https://www2.senado.leg.br/bdsf/bitstream/handle/id/512422/001041135.pdf>. Acesso em: 23 set. 2021.

CALAMANDREI, P. Direito processual civil. Tradução de Luiz Abezia e Sandra Fernandez Barbiery. Campinas: Bookseller, 1999.

CANOTILHO, G. J. J. Direito constitucional e teoria da constituição. 7. ed. Coimbra: Almedina, 2003.

COMOGLIO, L. P. Valori etici e ideologie del "giusto processo" (modelli a confronto). Rivista Trimestrale di Diritto e Procedura Civile, anno LII, n. 3, 1998.

COUTURE, E. Fundamentos del derecho procesal civil. 4. ed. Buenos Aires: Julio Cesar Faria, 2002.

DIDIER JR, F. Curso de direito processual civil. 18. ed. Salvador: JusPodivm, 2016.

DINIZ, M. H. Compêndio de introdução à ciência do direito. 24. ed. São Paulo: Saraiva, 2013.

FERRAZ JR, T. S. Introdução ao estudo do direito. 6. ed. São Paulo: Atlas, 2008.

FERRI, C. Sull'effettivitá del contraddittorio. Rivista trimestrale di Diritto e Procedura Civile, 1988. p. 781-782.

FRANCA, R. L. Hermenêutica jurídica. 2. ed. São Paulo: Saraiva, 1988.

MAGALHÃES, M. C. F. A hermenêutica jurídica. Rio de Janeiro: Forense, 1989.

MARINONI, L. G; ARENHART, S. C. Manual do processo de conhecimento. 4. ed. São Paulo: Revista dos Tribunais, 2005.

. Curso de processo civil. 2. ed. São Paulo: Revista dos Tribunais, 2016. O novo processo civil. 2. ed. São Paulo: Revista dos Tribunais, 2016.

MAXIMILIANO, C. Hermenêutica e aplicação do direito. 18. ed. Rio de Janeiro: Forense, 1999.

MEDINA, J. M. G. Novo código de processo civil comentado. 4. ed. São Paulo: Revista dos Tribunais, 2016.

NADER, P. Introdução ao estudo do direito. 37. ed. Rio de Janeiro: Forense, 2015.

NETO, M. A. L. Compêndio de introdução a ciência do direito. 5. ed. São Paulo: Saraiva, 1984.

PAULA, L. M. de. Curso de processo civil. E. ed. Belo Horizonte: D' Placido, 2016. 
SILVEIRA, A. Hermenêutica jurídica. São Paulo: Leia Livros, s.d.

STRECK. L. L. Hermenêutica jurídica e(m) crise. 5. ed. Porto Alegre: Livraria do Advogado, 2004.

THEODORO JUNIOR, H. Curso de direito processual civil. 50. ed. Rio de Janeiro: Forense, 2009.

Curso de direito processual civil: teoria geral do direito processual civil e processo de conhecimento. 47. ed. Rio de Janeiro: Forense, 2007.

Processo justo e contraditório dinâmico. Revista de Estudos Constitucionais, Hermenêutica e Teoria do Direito (RECHTD). São Leopoldo-RS. v. 2, n. 1. p. 64-71, 2010.

TROCKER, N. Il nuovo articolo 111 della costituzione e il "giusto processo" in materia civile: profi li generali. Rivista Trimestrale di Diritto e Procedura Civile, anno LV, n. 2, 2001.

WAMBIER, L. R; TALAMINI, E. Curso avançado de processo civil: cognição jurisdicional (processo comum de conhecimento). 16. ed. São Paulo: Revista dos Tribunais, 2016.

WAMBIER, L. R; WAMBIER, T. A. A. Doutrinas essenciais. São Paulo: Revista dos Tribunais, 2011

WAMBIER, T. A. A.; CONCEIÇÃO, M. L. L.; RIBEIRO, L. F. S.; MELLO, R. L. T. de. Primeiros comentários ao novo código de processo civil. 2. ed. São Paulo: Revista dos Tribunais, 2016. 